\title{
Public libraries in the "age of austerity": income generation and public library ethos
}

\author{
Hartwig Pautz, Alan Poulter
}

\begin{abstract}
The budgets of Britain's public services have been under sustained pressure and public libraries are no exception to public spending cuts in today's "age of austerity". Librarians increasingly try to supplement shrinking budgets by employing a variety of income generation methods. But are these methods always in line with the public library ethos? This article presents data showing what British librarians hold to be the public library ethos, what they undertake to generate extra income to maintain public library services and whether they think that their efforts to generate additional income are ever in contradiction to the public library ethos. The article is based on survey and interview data produced in 2013 and also provides, in a Supplementary File, a comprehensive list of income generation methods. The research methods only allowed for the production of non-generalisable data.
\end{abstract}

\section{Introduction and research questions}

Public libraries in the United Kingdom (UK) have had to confront a number of challenges in the recent past, many of them simultaneously: changing user needs, rising user expectations, an increasingly digital information world and doubts over the role, if any, of public libraries (e.g. Budd, 2008; de la Peña McCook and Phenix, 2011; Fiels, 2011; Hernon and Matthews, 2012; Kajberg, 2012; Dudley, 2013).

Another challenge has been that of public funding cuts, in particular since the onset of the "age of austerity" since 2010, following the financial crisis. These cuts have arguably already caused some damage to the British public library

\section{Authors}

Hartwig Pautz studied Information and Library Studies at the University of Strathclyde and is lecturer at the University of the West of Scotland.

Email: hartwig.pautz@arcor.de.

Alan Poulter has been lecturer in librarianship and information management for over 25 years after working at the British Library and the London Science Museum. 
system where libraries have been closing at a rate of two per week since 2010 and 4000 full-time staff have lost their employment (Ellis, 2013; also Davies, 2013). An end to cuts in public spending is not in sight. However, some library managers have tried to find solutions to the funding crisis by implementing ways to generate additional income.

This article presents results from research that scopes what public librarians in the UK do to generate additional income for their institution. It is based on Pautz's Masters dissertation in Information and Library Studies from the University of Strathclyde Masters (Pautz, 2013). The dissertation compares data from the US, the UK and Germany and can be obtained from the author.

The present study cannot be complete without addressing the ethical dimension of income generation in relation to the public library ethos. After all, public libraries subscribe to certain principles and the library profession has, over the decades, developed an ethos that might be compromised by income generation.

The following questions guided the research:

- What do librarians in the UK hold to be the public library ethos?

- What types of income generation activities are pursued by public libraries and which income generation activities are considered to be working best by librarians?

- What do librarians think about the compatibility of income generation methods with their ethos?

- What advice can be given with regard to income generation?

The research has three core objectives resulting from these questions: First, as a scoping study, it outlines what public libraries in the UK do in order to generate income. This results in a list of income generation methods to inform public librarians about what can be done to increase the financial foundations of their organisation (shown in the Supplementary File, Appendix 1). Second, the study shows what British librarians consider to be the ethical issues around income generation. Third, the analysis should help librarians to critically evaluate income generation methods in the light of their own organisation's needs and ethos.

The structure of the article is simple. A section on the methodology applied is followed by the presentation and discussion of data. A literature review and a discussion of what constitutes the public library ethos, according to the literature and professional codices by CILIP or IFLA, could not be included, given the brevity of the article and the richness of primary data discussed (for a discussion of this theme see Pautz (in press)). The comprehensive list of income generation methods is shown in the Supplementary File, together with the survey and interview questions used to generate the data.

\section{Methodology}

Primary data generated through two methods forms the foundation of this analysis: surveys and interviews. First, data was produced through an e-survey sent to public librarians to find out what kind of income generating activities are 
being pursued in the UK and whether librarians think that they are compatible with public library ethos. The survey was undertaken using Qualtrics software. The questionnaire was disseminated to public librarians via various channels. These included existing e-mailing lists, such as lis-profession@jiscmail.ac.uk and thelibrarycampaign@gmail.com. A short note on the research was published in the CILIP Update magazine. Posts about the research were featured on various websites (http://bestofpublib.wordpress.com and http://www.publiclibrariesnews.com/) and via individual mailings using e-mail obtained from Data.Gov.UK (Data.Gov.UK, 2012). Where incomplete or out of date, additional e-mail addresses were obtained from local authority's web pages.

All recipients of the e-survey were asked to circulate the survey within their organisation and to forward it to other public librarians of whatever role or level within a public library in Britain. The aim was to capture the views and experience of everybody working within a public library context. The demographic data of survey respondents show that the attempt to involve library staff from other levels than management had only limited success. Most respondents were library managers (37\%), fewer classified themselves as library assistants (22.8\%) (Figure 1).

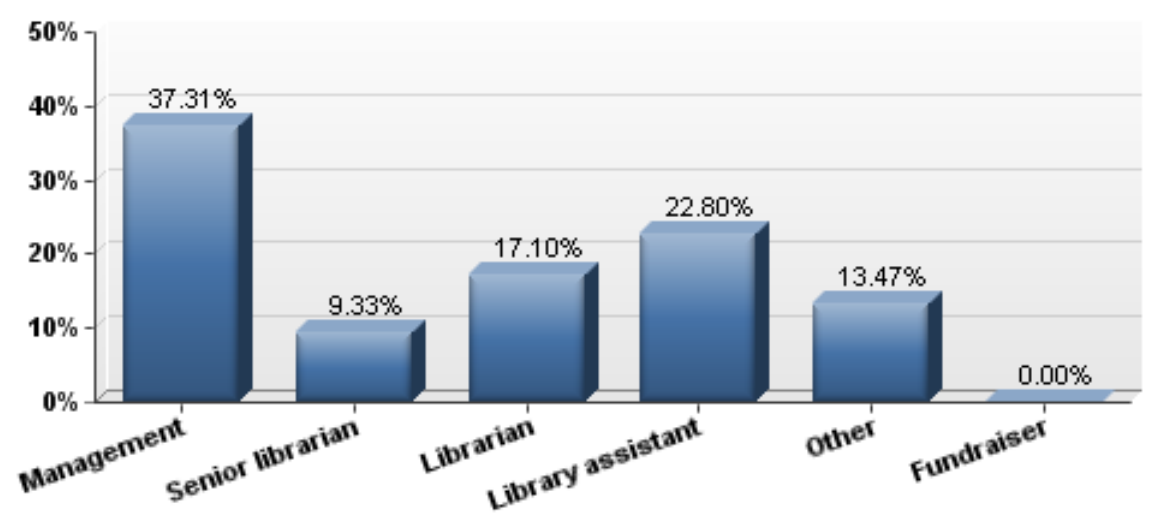

Figure 1: Position in library of UK respondents.

192 surveys were completed by respondents. While this may appear low in relation to the number of libraries and librarians in Britain, in many cases only one member within the senior management of a library authority took the survey. Furthermore, some libraries contacted the researcher to say that they would not participate in the research. Because the size of the population that was asked to take the survey is not known due to the distribution method it is not possible to calculate the response rate so that no claims to representativeness are made. The survey questionnaire can be found in Supplementary File, Appendix 2.

The second strand of data generation used semi-structured interviews with public librarians. The interview protocol presented in Appendix 2 ensured that a set of core questions was put to all interviewees while the nature of the semi-structured interviews allowed respondents "considerable liberty in expressing their definition of a situation that is presented to them" (Frankfort-Nachmias and Nachmias, 
2007, 225) and permitted the development of an understanding in depth rather than in breadth. Interviewees were guaranteed anonymity; interviews, between 45 and 90 minutes long, were recorded for analytical purposes only. Interviewees also had the opportunity to complete the survey questionnaire. For pragmatic reasons - i.e. limits to financial and time resources - only librarians at Scottish public libraries were interviewed. Of the six library authorities chosen, two served an urban, two a rural and two a mixed population. Five of the interviewees were library directors and a further five were in senior management positions; two of the latter were not qualified librarians.

Interviews and e-surveys have caveats in this instance, as they use a nonprobabilistic convenience sample, enlarged via snowball sampling relying on referrals from initial respondents to additional respondents, to generate data. Therefore, this research does not seek to make generalisable statements or develop a representative sample from the survey population. However, the data will be used to illustrate the thinking among British librarians on the issues of revenue generation and their implications for professional ethics.

\section{Discussion of the data}

With the research background, the research questions and the methodology outlined, this section presents and discusses the data obtained through survey and interviews.

\subsection{What is a public library and what should it do? The public library ethos}

Respondents were asked to indicate whether they agree or disagree, on a fivepoint scale, with a number of statements pertaining to the public library, its tasks and its underlying ethos. The answers reveal a fairly homogeneous understanding among those who took the survey, as Table 1 and Figure 2 show.

The results show that the social functions of the library as a meeting place or hub for the local community ( $97 \%$ agree/strongly agree), as a safe place for disadvantaged people (95\% agree/strongly agree) and the promotion of social inclusion (98\% agree/strongly agree) were particularly important for respondents. Also the educative and emancipative functions of the public library - with regards to information literacy and self-directed learning - were propositions which were supported by over $80 \%$ of survey respondents. Only two statements attracted any noticeable disagreements. A comparatively low $68 \%$ of respondents agreed/strongly agreed with the notion that the public library "supports the local business community", whilst $3.6 \%$ disagreed. Regarding the role of the library as a promoter of "knowledgeable citizens", $84 \%$ agreed or strongly agreed and 2\% disagreed.

In the interviews further characteristics of the public library ethos were emphasised. Central to the mission of the public library was the delivery of "high quality services" to the public. These services should give "people the best access to information, books, knowledge, as apolitically as possible" (Interview UK 1, 2013). Not dissimilar to other public services, public libraries were described as a service from "from womb to tomb" (Interview UK 2, 2013) available for "all 


\begin{tabular}{|c|c|c|c|c|c|}
\hline Statement & $\begin{array}{l}\text { Strongly } \\
\text { agree }\end{array}$ & Agree & $\begin{array}{l}\text { Neither } \\
\text { agree } \\
\text { nor } \\
\text { disagree }\end{array}$ & Disagree & $\begin{array}{l}\text { Strongly } \\
\text { disagree }\end{array}$ \\
\hline $\begin{array}{l}\text { It is an educator of the } \\
\text { local community. }\end{array}$ & $60.85 \%$ & $34.92 \%$ & $2.12 \%$ & $1.59 \%$ & $0.53 \%$ \\
\hline $\begin{array}{l}\text { It is a hub for the local } \\
\text { community. }\end{array}$ & $79.69 \%$ & $18.23 \%$ & $1.56 \%$ & $0.52 \%$ & $0.00 \%$ \\
\hline $\begin{array}{l}\text { It is a safe place for } \\
\text { vulnerable and } \\
\text { disadvantaged people. }\end{array}$ & $70.16 \%$ & $25.13 \%$ & $3.66 \%$ & $0.52 \%$ & $0.52 \%$ \\
\hline $\begin{array}{l}\text { It promotes } \\
\text { knowledgeable citizens. }\end{array}$ & $57.98 \%$ & $26.60 \%$ & $12.77 \%$ & $2.13 \%$ & $0.53 \%$ \\
\hline $\begin{array}{l}\text { It promotes social } \\
\text { inclusion. }\end{array}$ & $69.63 \%$ & $29.32 \%$ & $0.52 \%$ & $0.52 \%$ & $0.00 \%$ \\
\hline It promotes equality. & $66.49 \%$ & $28.27 \%$ & $5.24 \%$ & $0.00 \%$ & $0.00 \%$ \\
\hline $\begin{array}{l}\text { It supports the local } \\
\text { business community. }\end{array}$ & $23.16 \%$ & $45.26 \%$ & $27.89 \%$ & $3.68 \%$ & $0.00 \%$ \\
\hline $\begin{array}{l}\text { It is a meeting place for } \\
\text { everyone. }\end{array}$ & $63.35 \%$ & $28.27 \%$ & $7.33 \%$ & $1.05 \%$ & $0.00 \%$ \\
\hline $\begin{array}{l}\text { It is an internet access } \\
\text { point. }\end{array}$ & $93.23 \%$ & $6.77 \%$ & $0.00 \%$ & $0.00 \%$ & $0.00 \%$ \\
\hline $\begin{array}{l}\text { It provides access to } \\
\text { employment } \\
\text { information. }\end{array}$ & $57.81 \%$ & $37.50 \%$ & $4.17 \%$ & $0.52 \%$ & $0.00 \%$ \\
\hline $\begin{array}{l}\text { It is a place of self- } \\
\text { directed learning. }\end{array}$ & $59.69 \%$ & $36.65 \%$ & $3.14 \%$ & $0.00 \%$ & $0.52 \%$ \\
\hline $\begin{array}{l}\text { It promotes information } \\
\text { literacy }\end{array}$ & $65.45 \%$ & $28.80 \%$ & $5.24 \%$ & $0.00 \%$ & $0.52 \%$ \\
\hline $\begin{array}{l}\text { It enables free access to, } \\
\text { and free expression of, } \\
\text { information and ideas. }\end{array}$ & $56.54 \%$ & $32.46 \%$ & $10.47 \%$ & $0.00 \%$ & $0.52 \%$ \\
\hline $\begin{array}{l}\text { It helps customers to get } \\
\text { what they want. }\end{array}$ & $49.74 \%$ & $43.98 \%$ & $6.28 \%$ & $0.00 \%$ & $0.00 \%$ \\
\hline $\begin{array}{l}\text { It helps customers to get } \\
\text { what they need. }\end{array}$ & $52.63 \%$ & $43.16 \%$ & $4.21 \%$ & $0.00 \%$ & $0.00 \%$ \\
\hline $\begin{array}{l}\text { It is a place without } \\
\text { pressures to consume } \\
\text { anything. }\end{array}$ & $66.49 \%$ & $27.23 \%$ & $5.24 \%$ & $0.52 \%$ & $0.52 \%$ \\
\hline
\end{tabular}

Table 1: Describing the functions, principles and ethos of a public library. 


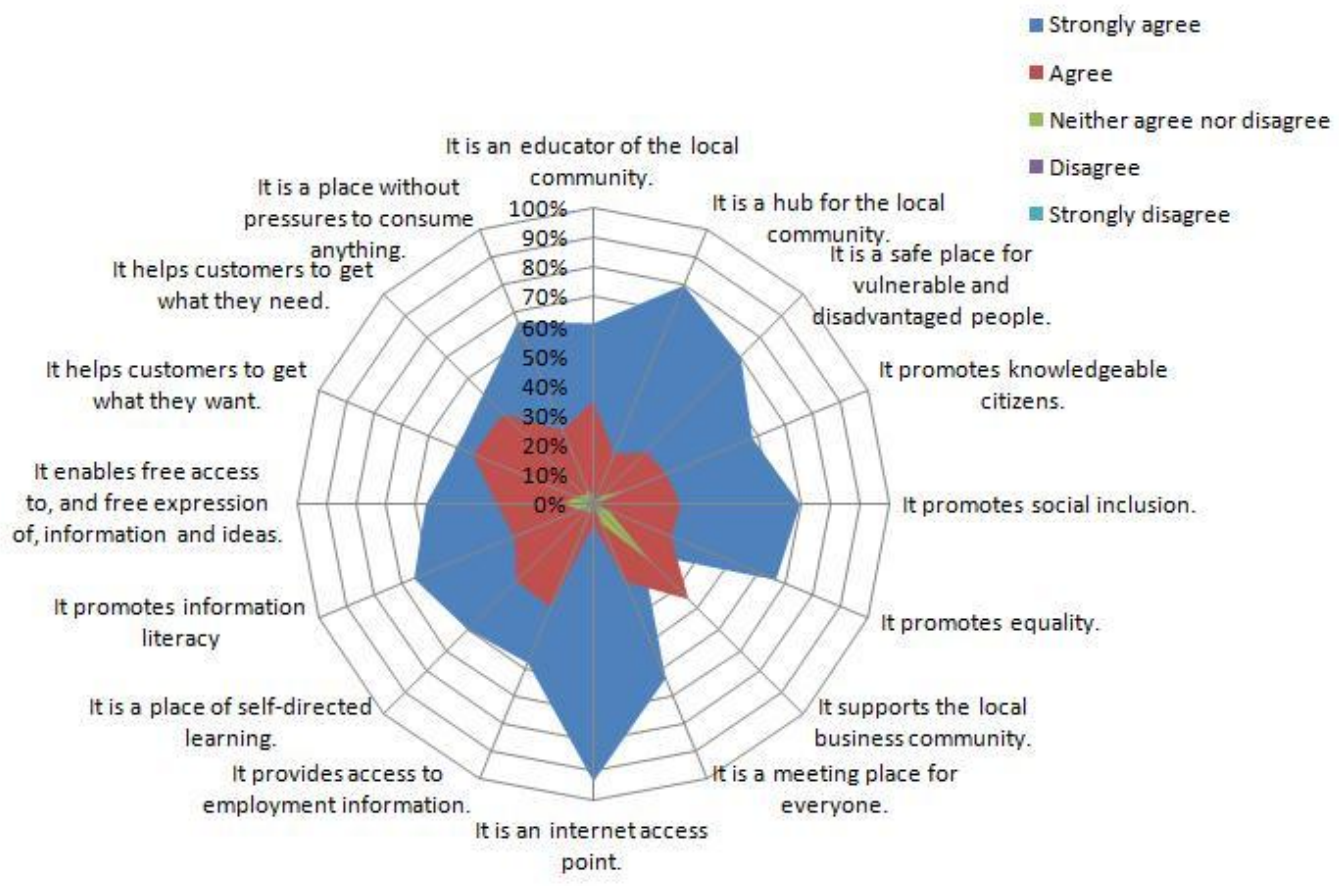

Figure 2: Describing the functions, principles and ethos of a public library.

members of the public. I ensure when people come in here they're all treated equally" (Interview UK 3, 2013).

\subsection{Supplementing public funding: income generation activities}

A central objective of the research was to scope what librarians actually do to generate additional income for maintaining and expanding library services. Respondents were asked to indicate whether they had applied any of the income generation methods presented to them as a list.

Figure 3 shows how many survey respondents have applied any of the over 20 income generation methods put to them. The most often used income generation method - selected by $90 \%$ of all respondents - is that of charging fees for printing and copying. The second most-used income generation methods were fines, followed by charges for audiovisual items and merchandise sales, reservation fees, room hire charges and events with admission fees. Only seven out of over twenty income generation items listed in the questionnaire were used by more than $50 \%$ of respondents. Table 2 ranks income generation methods according to frequency of use and additionally shows whether the methods have fulfilled expectations. The table shows that satisfaction rates are highest with government grants, sponsorships and charges for business advice.

While the survey data reveals which methods are the most frequently used and are most likely to meet expectations, the interview data allowed more in-depth insight into how librarians may think about income generation and whether some methods work better than others. 


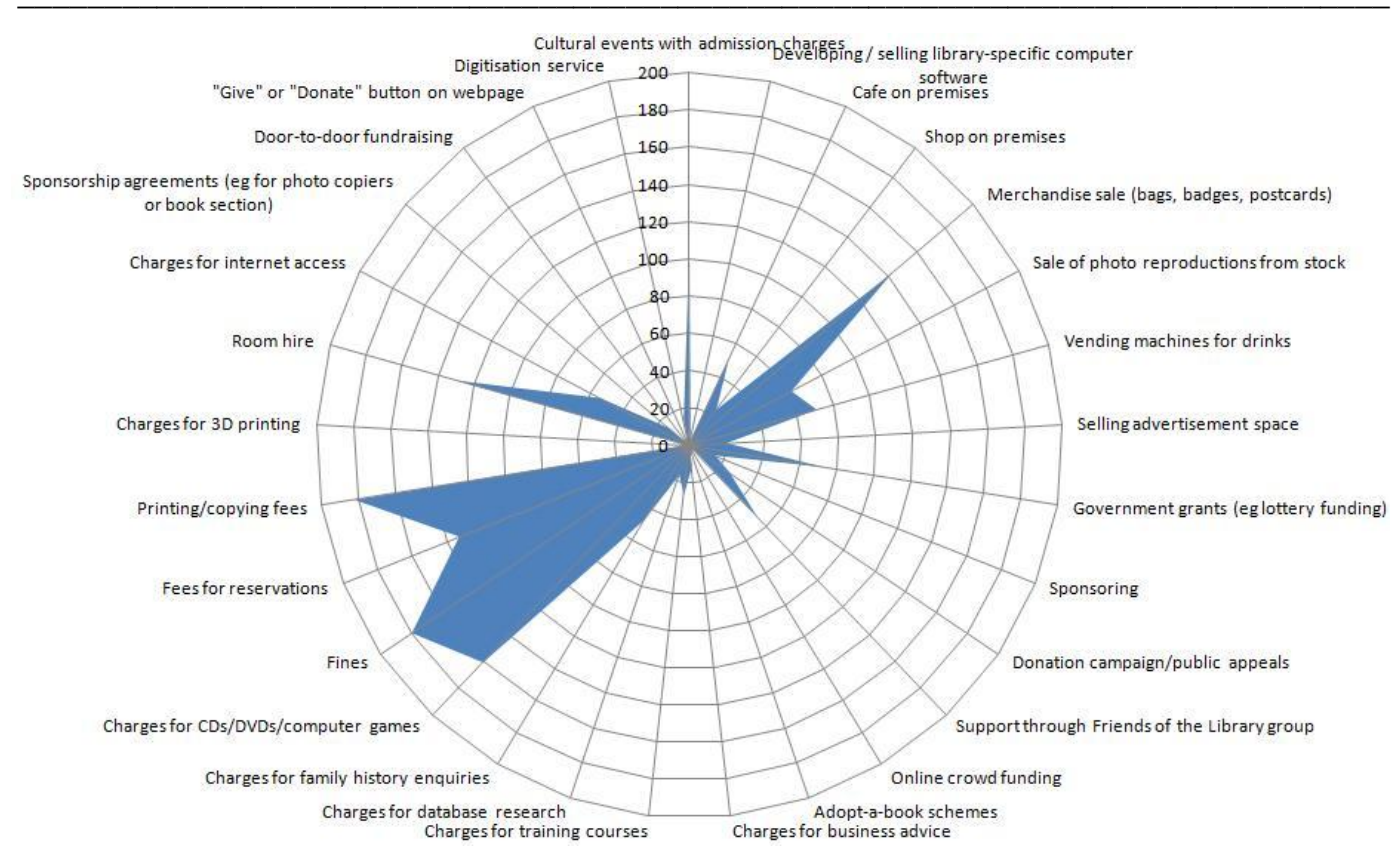

Figure 3: Used income generation methods by number of respondents having employed method (numbers of respondents from total).

One of the central themes that emerged from the interviews was "working in partnership" with organisations from the private, public or third sector in order to provide services. One librarian said that "we have become extremely good at, and that's what will see us through this economically challenging times, partnership working [...], not trying to do things on our own" (Interview UK 4, 2013). Another stated that "if there is a need in a particular area and others can provide that service, it's about getting into a mutually beneficial relationship" between library and external partners (Interview UK 2, 2013).

One example is cooperation between libraries, archives and private companies such as ancestry.co.uk. The private company digitises material of genealogical interest held by the former and makes it available online. Whenever an item is accessed, the holding library obtains a fee: "It looks to us as a win-win situation. We'll never have the resources to digitise that ourselves. It's also an opportunity to highlight our collections" (Interview UK 4, 2013) and "brings in people who would never come to an archive or library" (Interview UK 6, 2013).

The mentality of seeking partners and co-production of services seems to have been fostered by the cuts in public funding and growing expectations about the breadth of public library services: "Without partnerships there is no adequate library service" given the current funding climate (Interview UK 5, 2013). The consequences of such partnerships with external organisations deserve further detailed scrutiny. These partnerships are not always easy; for example, they can have effects on the public library's reputation for trustworthiness. Interviewees named, in particular, cooperation with local government - e.g. sharing premises with welfare or housing services - as potentially jeopardising citizens' faith in the independence of the information and advice they obtain from librarians: "The public often don't see the library as part of the Council" so they trust the 


\begin{tabular}{|c|c|c|}
\hline Income generation method & $\begin{array}{l}\text { Yes, we have } \\
\text { used this } \\
\text { method. (\% } \\
\text { of total } \\
\text { responses) }\end{array}$ & $\begin{array}{l}\text { Yes, the } \\
\text { method has } \\
\text { fulfilled our } \\
\text { expectations } \\
\text { (\% of those } \\
\text { who applied } \\
\text { method) }\end{array}$ \\
\hline Printing/copying fees & $90.60 \%$ & $61.50 \%$ \\
\hline Fines & $89.60 \%$ & $53.50 \%$ \\
\hline Charges for CDs/DVDs/computer games & $82.20 \%$ & $55.60 \%$ \\
\hline Merchandise sale (bags, badges, postcards) & $71.80 \%$ & $34.80 \%$ \\
\hline Fees for reservations & $65.60 \%$ & $50.80 \%$ \\
\hline Room hire & $65.60 \%$ & $52.30 \%$ \\
\hline Cultural events with admission charges & $54.70 \%$ & $54.20 \%$ \\
\hline Government grants (including lottery funding) & $35.90 \%$ & $84.00 \%$ \\
\hline Vending machines for drinks & $35.40 \%$ & $33.80 \%$ \\
\hline Sale of photo reproductions from library stock & $29.60 \%$ & $45.60 \%$ \\
\hline Charges for internet access & $27.60 \%$ & $45.30 \%$ \\
\hline Support through Friends of the Library group & $25.50 \%$ & $51.00 \%$ \\
\hline Café on premises & $25.50 \%$ & $28.50 \%$ \\
\hline Charges for family history enquiries & $22.90 \%$ & $31.80 \%$ \\
\hline Charges for training courses & $14.00 \%$ & $35.80 \%$ \\
\hline Donation campaign/public appeals & $13.50 \%$ & $26.90 \%$ \\
\hline Shop on premises & $12.50 \%$ & $45.80 \%$ \\
\hline $\begin{array}{l}\text { Selling advertisement space (on library } \\
\text { webpage or elsewhere) }\end{array}$ & $10.40 \%$ & $20.00 \%$ \\
\hline Charges for database research & $8.30 \%$ & $37.50 \%$ \\
\hline Sponsoring & $7.80 \%$ & $93.30 \%$ \\
\hline Digitisation service & $7.20 \%$ & $50.00 \%$ \\
\hline $\begin{array}{l}\text { Sponsorship agreements for individual items } \\
\text { (e.g. photo copiers or book section) }\end{array}$ & $6.60 \%$ & $63.20 \%$ \\
\hline Charges for business advice & $6.20 \%$ & $75.00 \%$ \\
\hline $\begin{array}{l}\text { Developing and selling library-specific } \\
\text { computer software }\end{array}$ & $1.50 \%$ & $100.00 \%$ \\
\hline Charges for 3D printing & $1.50 \%$ & $100.00 \%$ \\
\hline
\end{tabular}

Table 2: Income generation methods and satisfaction.

independence and unbiased quality of advice and information obtained there (UK Interview 7, 2013). This, according to another librarian, changes when a library physically "joins" up with (local) government services in which citizens may have less trust, having experienced them as part of the coercive state apparatus. Colocation can also have the somewhat less severe impact of diluting the library's identity. One interviewee reported about a partner organisation trying to take over 
"too much" of physical library space: "They felt they could almost dictate where they wanted to be. They would have overwhelmed us" (Interview UK 2, 2013).

While sponsorship agreements were only used by a surprisingly low $7 \%$ of the survey respondents - with a high satisfaction rate of $90 \%$ - interviewees commended such agreements: "Sponsors help to make your events, your organisation, stronger than you could have done it on your own" (Interview UK 8, 2013). Librarians should consider their institutions as attractive partners for sponsors: "Big buildings, lots of people, captive audience and full of people that sponsors would never get otherwise" (Interview UK 9, 2013). However, finding sponsors is easier for libraries operating in affluent areas, with a healthy local economy and where competition from museums or galleries is not too strong, as these more prestigious organisations tend to be more successful than public libraries when it comes to attracting sponsors (and also donors).

While sponsorship deals are meant to create benefits of equal value to the sponsoring organisation, donation campaigns appeal to the "philanthropic gene" of citizens. According to the survey data, about $13 \%$ of all respondents had used donation campaigns in the past to raise revenue for their library. Only a few interviewees reported that they followed a proper strategy when asking individuals or companies for donations; others described their approach as ad hoc. The legal status of the library services makes a large difference in this respect. Where public libraries have become charitable community interest companies, library managers are more active: "As a charity we're starting to think about how we get people to understand that they can give money to us. But it will be quite low-level, quite subtle, rather than 'give us money', because the Council is already giving us money" (Interview UK 1, 2013). However, accepting individual donations can be complicated as donors may want to wield what librarians consider undue influence over how their money is used. They:

want to give you money for "a thing" they can put their name on, and that's fine. But sometimes what we want is not the same. [...]. But you don't turn away money. As long as it doesn't drive us to doing things that we don't want to do.

(Interview UK 1, 2013)

For larger project-oriented fundraising drives interviewees considered an approach primarily aiming at "big money" from the "great and the good" more promising than seeking many smaller donations. Only when:

you've got the big donations together, you address the public and they may give money. Whereas if you're starting with the small donations, it's gonna be quite difficult to really generate enough interest about the project.

(Interview UK 4, 2013)

Such a view on how to fundraise for donations seems to be reflected in the relative lack of interest in using Friends of the Library groups as an income generation mechanism in the UK. Only a quarter of respondents said that they were using such a group to generate financial support for the library. In addition to experiences of such groups as not sufficiently effective for raising the required 
sums of money, some interviewees indicated that they considered Friends of the Library difficult to organise and manage. One interviewee provided an example:

What happened is that the group became controlled by one or two people and they ended up going off into all sorts of directions that we didn't want them to go in.

(Interview UK 1, 2013)

A further income generating method used by about $30 \%$ of survey respondents is digitising library-owned material and selling the digital copies. As Table 3 shows, over $50 \%$ of those applying this method indicated that their expectations were fulfilled. One major obstacle to the exploitation of photo stock and digital technology was the unavailability or cost of an adequate payment mechanism; here, partnerships with commercial providers were considered the best solution as local government was not trusted to successfully develop a payment mechanism for such purposes.

Another income generation method discussed here is that of grants from governments or foundations. While grants are an important income to enable libraries to pursue larger projects, they require considerable resources. First, libraries rarely have a dedicated grant-writing team and, second, once a grant application is successful they often have to re-direct staff to the new project: you have to pull people out of delivering the basic service to do something extra. That drives the funding and staffing away from the basic core services.

(Interview UK 1, 2013)

Some respondents also reported that there is a risk that "[you] chase funding for things you don't want to do" because of the pressure to acquire external grants (Interview UK 1, 2013).

Publishing - the last means of making income for the library to be discussed here - has become more and more difficult:

We used to sell local history publications, made by ourselves. When we started doing it there was a purpose, because nobody else was selling that kind of material. But now there are lots of small publishers doing that. Although we still sell them, we don't publish them anymore. It's not worth the amount of staff time.

(Interview UK 1, 2013)

The survey also generated data about income targets that fundraising activities are geared towards. Almost two thirds of all respondents report income generation targets (Figure 4).

Some interviewees and respondents indicated that "targets for income generation are wholly unrealistic and provide no real incentive [...]; they convey only a sense of failure" (Respondent UK 2, 2013). The continuously rising expectations with regard to income targets was described as "ridiculous" because:

if we beat an income target it is increased for the following year. This leads to the situation that one-off very popular events handicap the service by increasing the income target artificially. 


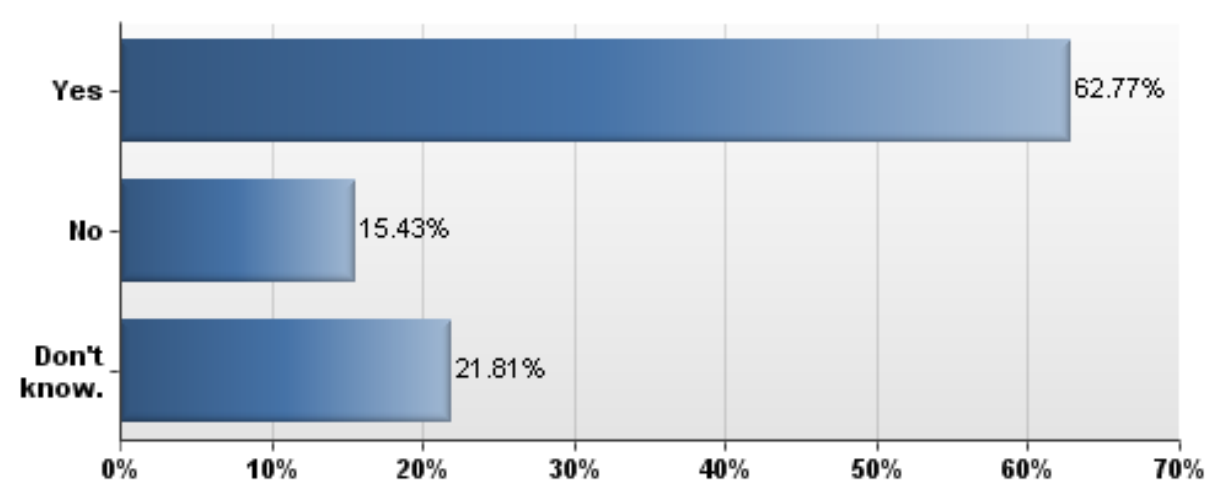

Figure 4: Do you have targets in your library for income generation?

Targets were also described as leading to fee-based services provision for which little or no thinking went into making the "business case":

I don't recall anybody writing a business case. I think it was the case of "we've got an income generation target to make, what do we think we can do to make some income, let's try this"

(Interview UK 7, 2013)

This situation is made even more complicated if income generated by the library is not ring-fenced for the library. A library manager said:

In the past, what's stopped us looking at income generation is that money that is generated tended to fall into the Council central pot. If I was generating vast sums of money I would want that money ring-fenced so that it can be ploughed back into the service.

(Interview UK 3, 2013)

This is different when libraries are no longer under direct local government control and may have a trading arm to generate profits that can be donated to the library.

\subsection{Ethos and income generation}

This section analyses data regarding the compatibility of income generation methods with what respondents held as the public library ethos. Respondents were asked to indicate whether any of the methods listed in the survey had in the past conflicted with the functions, principles and ethos of the public library.

Figure 5 shows that some methods were deemed problematic by survey respondents. Concerns related, in particular, to charges for internet access, reservations and training courses. Interviewees were clearly aware of the potential effects of charges and fines on the least economically privileged among their users: "I do not think that there should be charges for book loans or the internet as this would interfere with the learning-for-all ethos and increase barriers to the most vulnerable" (Respondent UK 5, 2013). Limiting free internet access to half an hour per day was described by one library manager as unjust: "At what point would you say your half hour is the same as my half hour? If I'm really slow on a 
PC, and you can touch-type, then you're going to get more out of your half hour than me" (Interview UK 2, 2013).

Respondents also indicated that events with admission charges, door-to-door fundraising and advertisement conflict with their ethos as public librarians. The survey and interview data may also indicate which services librarians see as "core" and which as mere "add-ons" since few ethical dilemmas were reported pertaining to charges for services such as 3D printing, digitisation or computer games and CD/DVD rental:

People look for more services in the libraries that would not have been seen previously as "natural", shall we say. An early thing would have been photocopiers. Why should there be photocopiers in libraries? [...] An additional service, not at all core to the library but useful to people.

(Interview UK 8, 2013)

Interviewees stated that "free information provision" was at the core of the public library service (Interview UK 4, 2013) but were not clear about what actually constituted "information". Some distinguished between written material and audio-visual material and considered the latter as "entertainment" for which charges were legitimate:

I don't see that as the role of the public library, to provide blockbuster films for free. [...] I see that more as entertainment. I have no qualms about charging for that because I don't feel that someone will be unable to function if they don't see the latest blockbuster.

(Interview UK 4, 2013)

Some interviewees and survey respondents emphasised positive aspects of feebased services. Fees, they said, can help to reduce demand for over-stretched services, in particular computer and internet services, to "responsible use": "Free access to literature and the internet can only be expected if used responsibly. I do not think it is inappropriate to charge fees where a lack of responsibility has taken place" in the form of using the internet for "nonsense" (Respondent UK 6, 2013). Furthermore, interviewees have seen that "if you make a small charge, for instance for an ICT course, attendance improves as some value has been attached to it" from the side of the "library customer" (Respondent UK 7, 2013).

However, there is a risk with fee-based services. They may be:

a service but they become like a cash cow as opposed to a fully integrated and thought-through offer [...]. It may have started as a service, but it became an income [...]. There is no strategy around that very often, it's just a matter of "this might make money for us and can offset a budget saving somewhere else".

(Interview UK 8, 2013)

Sponsorships are among the less contested income generation methods, according to the survey with over $60 \%$ of respondents stating that they had never experienced any ethical conflict. It requires trust in the sponsoring organisation's compatibility with the public library ethos: "There's awareness that sponsorship with the wrong people is worse than no sponsorship" (Interview UK 1, 2013). 
Therefore, librarians are careful not to take "sponsorship from an organisation that didn't meet our criteria for trust" (Interview UK 5, 2013).

Relatively minor income generation tools such as vending machines for soft drinks were discussed critically. One interviewee perceived hypocrisy in their institution's policies: “They've got Coke vending machines in here. We're talking about public health [in the library] and then we do that" (Interview UK 6, 2013). Three comments from survey and interviews conclude this section. One respondent takes a negative view on income generation which they see as:

neither an easy nor a successful strategy in public libraries. It creates a great tension between the service ethic, especially with regards to the disadvantaged sectors of society, and a more business-like ethic and, as a result, under-achieves all targets set.

(Respondent UK 8, 2013)

While others agreed that a particular "business ethos" was influencing their library's services, not all thought of that in a negative way: "Business thinking is not in conflict with the public library ethos. Public libraries are businesses, because they have to be" (Interview UK 8, 2013). Another stated that income generation is becoming more necessary in this financial climate. However, finding effective income generation is becoming increasingly more difficult. Especially, if you do not want to compromise the ethos of what a Library Service should be.

(Respondent UK 9, 2013)

\section{Income generation: recommendations}

The fourth objective of this article pertains to which recommendations can be made to public librarians about income generation using the primary data from surveys and interviews. It should be remembered that the data on which these recommendations are based is not generalisable and that the recommendations are based on the necessarily subjective deliberations, based on the data, of the authors.

- If library services are delivered through partnerships, then partners must be appropriate and not raise ethical issues for the collaborating library.

- Libraries should use their unique selling points - centrally located and heavily frequented buildings; trusted providers of information - more confidently in order to attract sponsorships of the appropriate kind. The librarian, when communicating with donors and sponsors, needs to feel assured about the accomplishments of the library and its societal relevance.

- Libraries should focus on the local business community for sponsorships and donation campaigns. The third sector seems more likely to be supportive. When sponsors are addressed, the librarian should be clear about what the library can offer in return.

- The philanthropic gene of library users could be tapped into more strategically by donation campaigns for specific projects and contributions via Friends of 
the Library groups. It is important that those asked for donations trust the library's abilities to make good use of its budget, that they understand what their donations will be used for and that their contribution allows the library to become even better than it already is. Donors are unlikely to give to an organisation they perceive as mal-functioning.

- Donation campaigns and Friends of the Library groups are never a quick cure to acute financial woes and librarians should see fundraising as a strategic and long-term approach. Fundraising is part of an institution's marketing strategy in that it is not only meant to generate resources but also establishes longlasting ties to friends and sponsors ("friend raising", e.g. Goldberg, 1994; Corson-Finnerty and Blanchard, 1998).

- Friends of the Library groups are difficult to organise and time-intensive and they take time to mature. However, the survey data suggests that they can work. If a public library decides to develop a Friends of the Library group it needs to decide whether the Friends of the Library group's central aim is to provide predominantly large-scale financial support or predominantly support through volunteering and smaller donations.

- Ethical codes pertaining to fees and charges, formulated by professional bodies or more locally, seem to have little impact on the income generation strategy at public libraries. Decisions are made by senior management mostly based on the necessity to generate more income but not on a thoroughly made business case which gives thought to the public library ethos. This does not mean that respondents and interviewees were not concerned about barriers to access through fees and charges but that professional codes were not seen as delimiting the range of actions available. Therefore librarians should develop a clear ethos and self-understanding, even if only for their local public library service.

\section{Conclusion}

The research has addressed income generating methods, public library ethos and its compatibility with income generation methods and thereby addressed a gap in the current professional literature. The current "age of austerity" has made discussion of income generation and public library ethos particularly urgent. The data and recommendations hopefully support librarians in their efforts to generate additional income for developing public library services with clear consideration of the implications for public library ethos and the general nature of the institution as a public service provider.

This article provided some evidence that public librarians' ethos and their understanding of the roles of the public library are widely shared but that highlevel ethos and principles are not always translated systematically into the day-today work of the organisation. When librarians scrutinise the list of income generation methods distilled from this research and provided as an Appendix in the Supplementary File, they need to ensure that their application not simply benefits their public library on a financial level but also that they do not undermine this widely shared public library ethos. 
The research presented here raises further questions. How do (non-)library users think about services and the free vs. fee debate? Which services - and for whom should be free of charge in their opinion? Which income generation mechanisms are acceptable? Furthermore, a thorough analysis of those income generation mechanisms described here as most promising and with least repercussions for the library ethos could support librarians in their effort to maximise income generation.

\section{References}

Budd, J.M. (2008) Self-Examination: The Present and Future of Librarianship. Westport, Connecticut: Libraries Unlimited.

Corson-Finnerty, A. and Blanchard, L. (1998) Fundraising and Friend-Raising on the Web. Chicago: American Library Association.

Data.Gov.UK. (2012) UK Public Library Contacts. URL: http://data.gov.uk/daaset/uk-public-library-contacts-14032012 [accessed 3.7.13].

de la Peña McCook, K. and Phenix, K. J. (2011) The Future of Public Libraries in the Twenty-first Century: Human Rights and Human Capabilities. In: de la Peña McCook, K. (eds) Introduction to Public Librarianship, 2nd ed. New York: Neal Schuman. 339-360.

Davies, S. (2013) The Public Library Service Under Attack. How Cuts are Putting Individuals and Communities at Risk and Damaging Local Businesses and Economies. [UNISON Local Government report June 2013]. URL: https://www.unison.org.uk/upload/sharepoint/On\%20line\%20Catalogue/21589.pd f [accessed 4.6.13].

Dudley, M. (ed.) (2013) Public Libraries and Resilient Cities. Chicago: American Library Association.

Ellis, M. (2013) Jobless Forced to Pay for Library Internet Access Just as More Services Move Online. The Mirror, [18 June 2013]. URL:

http://www.mirror.co.uk/news/uk-news/jobless-forced-pay-library-internet$\underline{1959330}$ [accessed 19.6.13].

Fiels, K. M. (2011) A Library "State of the State": Trends, Issues, and Myths. In: Woodsworth, A. (ed.) Librarianship in Times of Crisis. London: Emerald Group Publishing Limited. 3-17.

Frankfort-Nachmias, C. and Nachmias. D. (2007) Study Guide for Research Methods in the Social Sciences. London: Worth Publishers.

Goldberg S. (1994) Fund Raising, Friend Raising: The San Antonio Public Library Foundation, The Bottom Line: Managing Library Finances, 7(1), 37-39.

Hernon, P. and Matthews, J. R. (2012) Reflecting on the Future of Academic and Public Libraries. London: Facet. 
Interview UK 1. (2013) Interview with researcher, July 2013. [Interviewee is director at a rural library].

Interview UK 2. (2013) Interview with researcher, July 2013. [Interviewee is senior librarian at a rural library].

Interview UK 3. (2013) Interview with researcher, July 2013. [Interview is director at a rural library].

Interview UK 4. (2013) Interview with researcher, July 2013. [Interviewee is director of a large urban library].

Interview UK 5. (2013) Interview with researcher, July 2013. [Interviewee is director of a large urban library].

Interview UK 6. (2013) Interview with researcher, July 2013. [Interviewee is senior librarian at urban library].

Interview UK 7. (2013) Interview with researcher, July 2013. [Interviewee is director of library in a mostly rural area].

Interview UK 8. (2013) Interview with researcher, July 2013. [Interviewee is manager at large urban library].

Interview UK 9. (2013) Interview with researcher, July 2013. [Interviewee is fundraiser at a large urban library].

Kajberg, L. (2012) Re-examining the Values of the Public Library in Times of Uncertainty and Hardship: a Discussion of Theoretical Ideas Inspired by Axel Honneth's Observations on Social Freedom. [Revised edition of a paper presented at the Anniversary Event of the Swedish School of Library and Information Science in Borås, December 2012]. URL: http://www.b2i.de/fileadmin/dokumente/BFP_Preprints_2013/Preprint-Artikel2013-AR-2888-Kajberg.pdf [accessed 6.7.13].

Pautz, H. (2013). Income Generation in Public Libraries and its Influence on Public Library Ethos, [MSc thesis, Department of Computer and Information Sciences, University of Strathclyde]. URL:

http://www.strath.ac.uk/cis/research/mastersthesis/?abstract=2658 [accessed 18.5.14].

Pautz, H. (in press) Income Generation in Public Libraries: Potentials and Pitfalls. Library Review.

Respondent UK 2. (2013) Statement from anonymous electronic survey. July 2013. [Respondent is manager at urban library in England].

Respondent UK 3. (2013) Statement from anonymous electronic survey. July 2013. [Respondent is manager at rural library in England].

Respondent UK 5. (2013) Statement from anonymous electronic survey. July 2013. [Respondent is senior librarian at urban library in England].

Respondent UK 6. (2013) Statement from anonymous electronic survey. July 2013. [Respondent is manager at urban library in England]. 
Respondent UK 7. (2013) Statement from anonymous electronic survey. July 2013. [Respondent is manager at urban library in England].

Respondent UK 8. (2013) Statement from anonymous electronic survey. July 2013. [Respondent is senior librarian at urban library in England].

Respondent UK 9. (2013) Statement from anonymous electronic survey. July 2013. [Respondent is director at an urban library in England].

\section{Open access and copyright}

Library and Information Research is an open access journal. A freely available copy of this paper may be downloaded from the journal's website:

http://www.lirgjournal.org.uk.

Copyright and associated moral rights in works published in Library and Information Research are retained by the author(s) but this paper may be used freely, with proper attribution, in educational and other non-commercial settings. 